\title{
Pola kelainan tiroid di RSUP Prof. Dr. R. D. Kandou Manado periode Januari 2013 - Desember 2015
}

\author{
${ }^{1}$ Henry Crosby \\ ${ }^{2}$ Victor Pontoh \\ ${ }^{2}$ Marselus A. Merung \\ ${ }^{1}$ Kandidat Skripsi Fakultas Kedokteran Universitas Sam Ratulangi Manado \\ ${ }^{2}$ Bagian Bedah RSUP Prof. Dr. R. D. Kandou Manado \\ Email: henrycrosby12101@gmail.com
}

\begin{abstract}
Thyroid disorders are the second most common endocrine disorders in the world after diabetes. The most common thyroid disorders are goitre, Graves' disease, Hashimoto's thyroiditis, and thyroid neoplasm. This study was aimed to determine the pattern of thyroid disorder at Prof. Dr. R. D. Kandou Hospital Manado from January 2013 to December 2015. This was a descriptive retrospective study. Data were obtained from Medical Rrecord Installation and Departement of Pathology at Prof. Dr. RD Kandou Hospital Manado periods January 2013 - December 2015. The results showed that of total 244 cases of thyroid disorders the highest percentage was in the period January - December 2015 ias many as 132 cases (54.1\%) consisted of $196(80.3 \%)$ females and 48 (19.7\%) males. Most patients were in the age group 51-60 years $(24.2 \%)$ amd lived in mountainous area (66.7\%). The most common pathological results were benign colloid goitre $(71.9 \%)$ and papillary carcinoma $(62.7 \%)$. Since the incidence of thyroid disorders continues to rise each year at Prof. Dr. R. D. Kandou Hospital Manado, prevention and education to patients with thyroid disorders are needed to minimalize the complications of thyroid disorders.
\end{abstract}

Keywords: thyroid disorder

\begin{abstract}
Abstrak: Kelainan kelenjar tiroid merupakan kelainan endokrin terbanyak kedua di dunia setelah diabetes. Kelainan tiroid yang paling sering terjadi ialah goiter, penyakit Grave, tiroiditis Hashimoto, dan neoplasma tiroid. Penelitian ini bertujuan ntuk mengetahui pola kelainan tiroid di RSUP Prof. Dr. R. D. Kandou periode Januari 2013 - Desember 2015. Jenis penelitian ialah deskriptif retrospektif. Data diperoleh dari Instalasi Rekam Medik dan Bagian Patologi Anatomi RSUP. Prof. Dr. R. D. Kandou Manado periode Januari 2013 - Desember 2015. Hasil penelitian memperlihatkan bahwa dari 244 kasus kelainan tiroid terbanyak pada periode Januari - Desember 2015 yaitu 132 kasus (54,1\%), terdiri dari 196 (80,3\%) perempuan dan $48(19,7 \%)$ laki-laki. Penderita terbanyak pada kelompok usia 51-60 tahun $(24,2 \%)$ dan bertempat tinggal di daerah pegunungan $(66,7 \%)$. Jenis hasil patologi anatomi jinak dan ganas terbanyak ialah struma koloides $(71,9 \%)$ dan karsinoma papiler $(62,7 \%)$.Oleh karena angka kejadian kelainan tiroid terus meningkat setiap tahunnya di RSUP Prof. Dr. R. D. Kandou Manado, upaya preventif dan edukasi terhadap penderita kelainan tiroid diperlukan untuk mengurangi komplikasi kelainan tiroid.
\end{abstract}

Kata kunci: kelainan tiroid

Penyakit atau kelainan tiroid adalah suatu kondisi kelainan pada seseorang akibat adanya gangguan kelenjar tiroid, baik berupa perubahan bentuk maupun perubahan fungsi. ${ }^{1}$ Kelainan pada kelenjar tiroid ini merupakan kelainan endokrin terbanyak kedua di dunia setelah diabetes. Sekitar 300 juta orang di dunia dilaporkan 
menderita kelainan tiroid, namun lebih dari setengahnya tidak menyadarinya. ${ }^{2,3}$ India merupakan negara dengan penderita kelainan tiroid paling banyak, yaitu sekitar 42 juta orang. ${ }^{2}$ Kelainan kelenjar tiroid juga menjadi masalah kesehatan utama di Nepal dengan prevalensi mendekati $30 \%$ dari populasi. ${ }^{3}$ Di Pakistan, 8 juta orang penduduk mengalami kelainan tiroid akibat kekurangan yodium. ${ }^{4}$ Kelainan tersebut juga banyak terjadi di negara-negara seperti Bangladesh, Bhutan, Burma, Sri Lanka, dan Thailand. ${ }^{5}$ Di Amerika Serikat dengan jumlah penduduk lebih dari 275 juta, diperkirakan sekitar 20 juta orang mengalami berbagai kelainan tiroid dan paling banyak terjadi pada perempuan.,

Kelainan pada tiroid mencakup kondisi yang berkaitan baik dengan pengeluaran berlebihan hormon tiroid maupun yang berkaitan dengan defisiensi hormon tiroid, serta lesi massa tiroid. ${ }^{8}$ Menurut peneliti di Saudi Arabia, kelainan tiroid yang sering terjadi ialah struma, penyakit Grave, tiroiditis Hashimoto, dan neoplasma tiroid. Dua dari kelainan utama kelenjar tiroid tersebut merupakan gangguan autoimun yaitu tiroiditis Hashimoto dan penyakit Grave. ${ }^{9} \quad$ Gangguan autoimun tiroid mengenai sekitar $2-4 \%$ populasi perempuan dan lebih dari $1 \%$ populasi laki-laki di dunia, dengan jumlah tercatat terbanyak di negara Amerika Serikat dan Jepang. ${ }^{10}$ Menurut kepustakaan Barat, sekitar 50\% orang dalam masyarakat memiliki nodul yang sangat kecil, 15\% dengan struma atau goitre, dan 3,5\% dengan karsinoma papilar. ${ }^{11,12}$ Dari kelainan tersebut, struma merupakan kelainan yang paling sering ditemukan. Sekitar 102 juta orang di dunia mengalami kelainan ini. ${ }^{5}$ Karsinoma tiroid merupakan keganasan dengan angka mortalitas yang lebih tinggi. Angka kematian akibat kanker tiroid berkisar 0,6 per 100.000 penduduk pada laki-laki dan 1,2 per 100.000 penduduk pada perempuan. ${ }^{13,14}$

Di Indonesia, data statistik mengenai kelainan tiroid masih sangat kurang. ${ }^{7}$ Berdasarkan hasil survei di seluruh Indonesia mengenai struma menunjukkan peningkatan prevalensi Total Goitre Rate (TGR) dari 9,8\% pada tahun 1998 menjadi sebesar $11,1 \%$ pada tahun 2003. Angka TGR di Indonesia tersebut masih menjadi masalah kesehatan masyarakat, karena WHO memberi batas maksimal 5\%. ${ }^{15,16}$ Berdasarkan laporan dari Badan Registrasi Kanker Ikatan Dokter Ahli Patologi Indonesia (IAPI) tahun 1998 kanker tiroid menempati urutan ke sembilan dari 10 kanker terbanyak. ${ }^{17-21}$ Di Rumah Sakit Kanker Dharmais, kanker tiroid menempati urutan ke enam terbanyak dari kanker lainnya. Angka kejadian kanker tiroid ini cenderung meningkat dari 85 kasus kanker tiroid pada tahun 2010 menjadi 147 kasus pada tahun $2013 .^{22}$

Prevalensi kelainan tiroid dipengaruhi oleh jenis kelamin dan usia. Kelainan kelenjar tiroid pada wanita terjadi 4 hingga 10 kali lebih sering dibandingkan dengan pria. ${ }^{15}$ Berdasarkan uraian di atas serta kurangnya data di Indonesia mengenai kelainan tiroid, maka dilakukan penelitian untuk mengetahui pola kelainan tiroid di RSUP Prof. Dr. R. D. Kandou Manado periode Januari 2013 sampai dengan Desember 2015.

\section{METODE PENELITIAN}

Jenis penelitian ialah deskriptif retrospektif dengan menggunakan data sekunder di Instalasi Rekam Medik dan Bagian Patologi Anatomi RSUP Prof. Dr. R. D. Kandou Manado. Penelitian dilakukan pada bulan Oktober sampai Desember 2015. Sampel penelitian ialah pasien kelainan tiroid di RSUP Prof. DR. R. D. Kandou Manado periode Januari 2013 sampai dengan Desember 2015 dengan memperhatikan kriteria inklusi dan eksklusi. Yang termasuk kriteria inklusi penelitian ini ialah pasien yang didiagnosis menderita kelainan tiroid dengan pembesaran kelenjar tiroid disertai hasil pemeriksaan patologi anatomi di RSUP Prof. Dr. R. D. Kandou Manado periode Januari 2013 - Desember 2015. Yang termasuk kriteria eksklusi penelitian ini ialah pasien yang menderita kelainan tiroid yang dilakukan pemeriksaan klinis saja tapi 
tidak dilengkapi hasil pemeriksaan patologi anatomi di RSUP Prof. DR. R. D. Kandou Manado periode Januari 2013 - Desember 2015.

\section{HASIL PENELITIAN}

Berdasarkan penelitian yang dilakukan di Instalasi Rekam Medik dan Bagian Patologi Anatomi RSUP Prof. Dr. R. D. Kandou didapatkan data kasus kelainan tiroid periode Januari 2013 - Desember 2015 sebanyak 244 kasus.

Tabel 1 memperlihatkan kasus kelainan tiroid pada periode JanuariDesember 2013 sebanyak 43 kasus (17,6\%), periode Januari-Desember 2014 sebanyak 69 kasus (28,3\%), dan periode Januari-Desember 2015 sebanyak 132 kasus $(54,1 \%)$.

Tabel 2 dan Gambar 1 memperlihatkan frekuensi penderita kelainan tiroid berdasarkan usia. Golongan usia yang terbanyak ialah usia 51-60 tahun sebanyak 59 orang $(24,2 \%)$ sedangkan yang paling sedikit ialah usia $\leq 20$ tahun sebanyak 6 orang $(2,5 \%)$.

Gambar 2 memperlihatkan penderita kelainan tiroid dengan jenis kelamin perempuan sebanyak 196 orang $(80,3 \%)$ sedangkan laki-laki sebanyak 48 orang $(19,7 \%)$

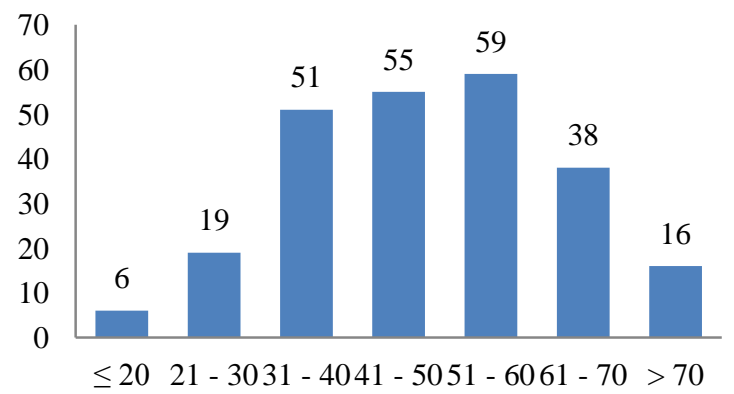

Gambar 1. Diagram distribusi penderita kelainan tiroid menurut umur

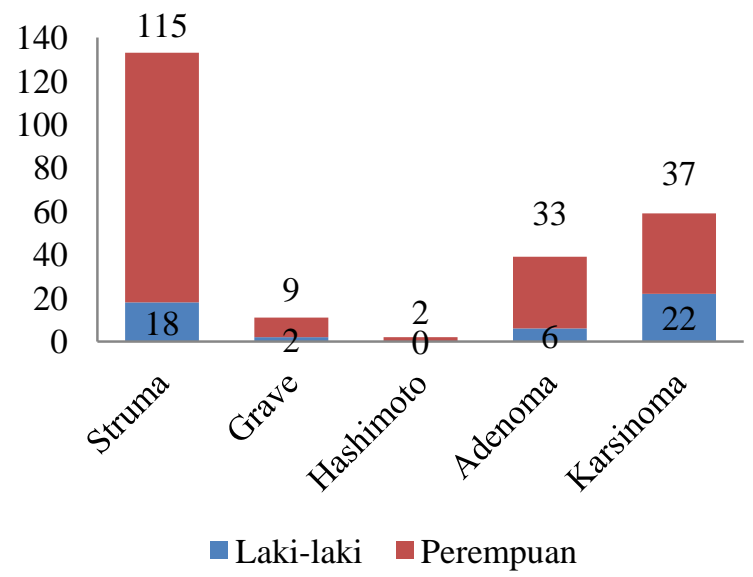

Gambar 2. Diagram distribusi penderita kelainan tiroid menurut jenis kelamin

Tabel 1. Angka kejadian kelainan tiroid menurut tahun di RSUP Prof. Dr. R. D. Kandou Manado

\begin{tabular}{|c|c|c|c|c|c|c|c|c|}
\hline \multirow{2}{*}{ Periode } & \multicolumn{5}{|c|}{ Jumlah Penderita } & \multirow[b]{2}{*}{$\%$} & \multirow{2}{*}{ Jumlah } & \multirow{2}{*}{$\%$} \\
\hline & Struma & $\%$ & Autoimun & $\%$ & Neoplasma & & & \\
\hline 2013 & 26 & $10,7 \%$ & 1 & $0,4 \%$ & 16 & $6,6 \%$ & 43 & $17,6 \%$ \\
\hline 2014 & 39 & $16,0 \%$ & 3 & $1,2 \%$ & 27 & $11,1 \%$ & 69 & $28,3 \%$ \\
\hline 2015 & 68 & $27,9 \%$ & 9 & $3,7 \%$ & 55 & $22,5 \%$ & 132 & $54,1 \%$ \\
\hline Total & 133 & $54,5 \%$ & 13 & $5,3 \%$ & 98 & $40,2 \%$ & 244 & $100,0 \%$ \\
\hline
\end{tabular}

Tabel 2. Distribusi penderita kelainan tiroid menurut usia

\begin{tabular}{|c|c|c|c|c|c|c|c|c|c|c|c|c|}
\hline \multirow{2}{*}{$\begin{array}{c}\text { Usia } \\
\text { (tahun) }\end{array}$} & \multicolumn{3}{|c|}{ Struma } & \multicolumn{2}{|l|}{ Grave } & \multicolumn{2}{|c|}{ Hashimoto } & \multirow{2}{*}{$\frac{\text { Adenoma }}{\%}$} & \multicolumn{2}{|c|}{ Karsinoma } & \multirow{2}{*}{ Jumlah } & \multirow{2}{*}{$\%$} \\
\hline & $\mathrm{n}$ & $\%$ & $\mathrm{n}$ & $\%$ & $\mathrm{n}$ & $\%$ & $\mathrm{n}$ & & $\mathrm{n}$ & $\%$ & & \\
\hline$\leq 20$ & 2 & $0,8 \%$ & 1 & $0,4 \%$ & 0 & $0,0 \%$ & 3 & $1,2 \%$ & 0 & $0,0 \%$ & 6 & $2,5 \%$ \\
\hline $21-30$ & 8 & $3,3 \%$ & 1 & $0,4 \%$ & 2 & $0,8 \%$ & 4 & $1,6 \%$ & 4 & $1,6 \%$ & 19 & $7,8 \%$ \\
\hline $31-40$ & 34 & $13,9 \%$ & 4 & $1,6 \%$ & 0 & $0,0 \%$ & 5 & $2,0 \%$ & 8 & $3,3 \%$ & 51 & $20,9 \%$ \\
\hline $41-50$ & 34 & $13,9 \%$ & 4 & $1,6 \%$ & 0 & $0,0 \%$ & 9 & $3,7 \%$ & 8 & $3,3 \%$ & 55 & $22,5 \%$ \\
\hline $51-60$ & 33 & $13,5 \%$ & 0 & $0,0 \%$ & 0 & $0,0 \%$ & 9 & $3,7 \%$ & 17 & $7,0 \%$ & 59 & $24,2 \%$ \\
\hline $61-70$ & 12 & $4,9 \%$ & 1 & $0,4 \%$ & 0 & $0,0 \%$ & 6 & $2,5 \%$ & 19 & $7,8 \%$ & 38 & $15,6 \%$ \\
\hline$>70$ & 10 & $4,1 \%$ & 0 & $0,0 \%$ & 0 & $0,0 \%$ & 3 & $1,2 \%$ & 3 & $1,2 \%$ & 16 & $6,6 \%$ \\
\hline Total & 133 & $54,5 \%$ & 11 & $4,5 \%$ & 2 & $0,8 \%$ & 39 & $16,0 \%$ & 59 & $24,2 \%$ & 244 & $100,0 \%$ \\
\hline
\end{tabular}


Gambar 3 memperlihatkan bahwa kasus kelainan tiroid yang terjadi di daerah pegunungan sebanyak 152 kasus $(66,7 \%)$, sedangkan kasus kelainan tiroid yang terjadi di daerah pesisir pantai sebanyak 76 kasus (33,3\%) (Gambar 3).

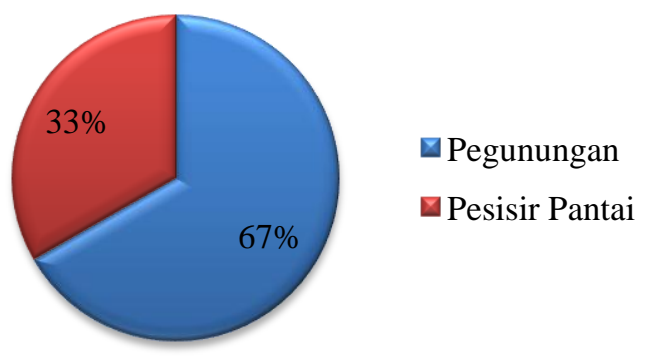

Gambar 3. Diagram distribusi penderita kelainan tiroid menurut tempat tinggal

Gambar 4 memperlihatkan distribusi frekuensi penderita kelainan tiroid jinak menurut jenis histopatologik. Jumlah penderita kelaian tiroid dengan jenis histopatologik struma koloides sebanyak 133 kasus (71,9\%), penyakit Grave sebanyak 11 kasus $(5,9 \%)$, tiroiditis Hashimoto sebanyak 2 kasus $(1,1 \%)$, adenoma folikular sebanyak 33 kasus $(17,8 \%)$, dan adenoma papilar sebanyak 6 kasus $(3,2 \%)$.

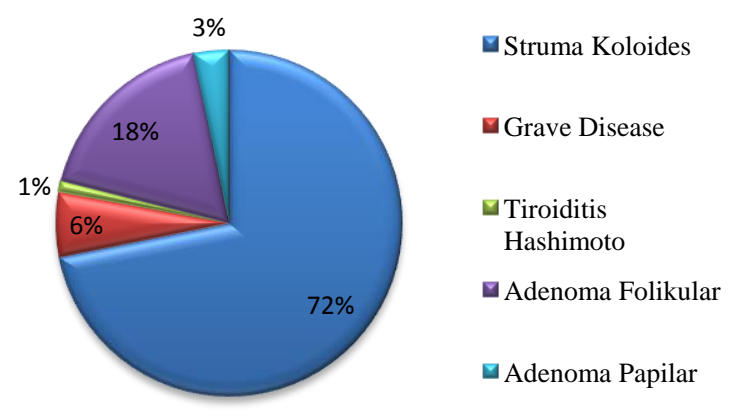

Gambar 4. Diagram distribusi penderita kelainan tiroid jinak menurut jenis histopatologi

Dari gambar 5 dapat dilihat distribusi frekuensi penderita kelainan tiroid ganas menurut jenis histopatologik. Jumlah kasus kelainan tiroid dengan karsinoma tiroid papilar yaitu sebanyak 37 kasus $(62,7 \%)$, karsinoma papilar varian folikular sebanyak 1 kasus (1,7\%), karsinoma folikular sebanyak 13 kasus (22,0\%), karsinoma medular sebanyak 1 kasus $(1,7 \%)$, dan karsinoma anaplastik sebanykak 7 kasus $(11,9 \%)$.

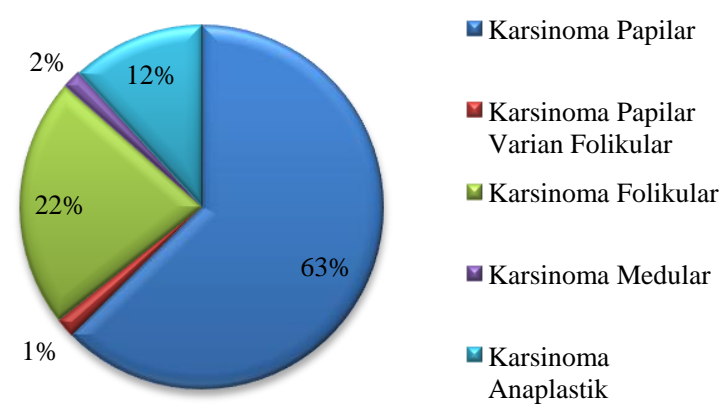

Gambar 6. Distribusi penderita kelainan tiroid ganas menurut jenis histopatologi

\section{BAHASAN}

Berdasarkan hasil penelitian yang ditemukan kelainan tiroid di RSUP Prof. Dr. R. D. Kandou Manado periode Januari 2013 sampai Desember 2015 sebanyak 244 kasus. Kelainan tiroid yang ditemukan selama periode tersebut ialah struma tiroid, penyakit Grave, tiroiditis Hashimoto, dan neoplasma tiroid. Distribusi frekuensi berdasarkan tahun mencapai puncak pada periode Januari sampai dengan Desember 2015 yaitu 54,1\%. Kelainan tiroid yang paling banyak ditemukan ialah struma tiroid yaitu 54,5\%. Angka kejadian sebanyak 244 kasus ini dibagi ke dalam distribusi frekuensi menurut usia, jenis kelamin, tempat tinggal, dan jenis histopatologi.

Penderita struma tiroid terbanyak pada golongan usia 31-40 tahun dan 41-50 tahun, disusul golongan usia 51-60 tahun, dan golongan usia 61-70 tahun. Hal ini sesuai dengan penelitian Assagaf et al. ${ }^{23}$ (2015) yang mengatakan bahwa struma dapat menyerang penderita pada segala usia namun usia yang semakin tua akan meningkatkan risiko penyakit lebih besar. Hal ini disebabkan karena daya tahan tubuh dan imunitas seseorang yang semakin 
menurun seiring dengan bertambahnya usia dan meningkatnya kebutuhan terhadap asupan yodium. Frekuensi struma meningkat seiring dengan usia, tetapi dalam area endemik yang berat, struma dapat ditemukan pada kelompok praremaja. ${ }^{23}$ Pada penelitian ini, usia pasien yang menderita struma tiroid mulai dari usia dewasa sampai dengan usia tua. Hal ini dapat berhubungan dengan peningkatan risiko penyakit seiring dengan bertambahnya usia. Tingginya frekuensi penderita pada interval usia 41-50 tahun dapat disebabkan karena tingginya insiden penyakit struma tiroid pada kelompok usia ini.

Golongan usia penderita penyakit Grave terbanyak ialah golongan usia 31-40 tahun dan 41-50 tahun. Maitra dan $\mathrm{Kumar}^{8}$ menyatakan bahwa insiden puncak penyakit Grave antara usia 20 dan 40 tahun. Golongan usia penderita tiroiditis Hashimoto terdapat pada golongan usia 2130 tahun. Hal ini tidak sesuai dengan kepustakaan yang mengatakan bahwa tiroiditis Hashimoto paling sering terjadi antara usia 45 dan 65 tahun.

Golongan usia pasien yang di diagnosis karsinoma tiroid terbanyak ialah golongan usia 61-70, disusul golongan usia 51-60 tahun kemudian golongan usia 31-40 tahun dan 41-50 tahun. Insiden karsinoma tiroid meningkat seiring bertambahnya usia. Selain itu, faktor risiko terkena karsinoma tiroid ialah usia kurang dari 20 tahun dan lebih dari 50 tahun. Hal ini sesuai dengan data yang diperoleh, dimana angka kejadian karsinoma yang paling banyak diperoleh pada golongan usia 61-70 atau lebih dari 50 tahun. ${ }^{21}$

Dari data pada tabel penggolongan jenis kelamin penderita kelainan tiroid terbanyak ialah perempuan yaitu sebanyak $80,3 \%$, sedangkan laki-laki sebanyak 19,7\%. Bila disajikan dalam perbandingan, maka didapatkan perbandingan jumlah penderita perempuan terhadap penderita laki-laki ialah 4,1:1. Hasil ini sesuai dengan kepustakaan yang menyatakan bahwa prevalensi kelainan tiroid lebih sering terjadi pada perempuan. Hal ini disebabkan pengaruh hormon pada perempuan merupakan salah satu faktor predisposisi meningkatnya jumlah pasien perempuan dibandingkan laki-laki. Estrogen dapat meningkatkan kadar thyroid binding globulin (TBG) yang bekerja sebagai transpor T4 dan T3 dalam darah sehingga terjadi penurunan kadar T4 bebas dan T3 bebas. Hal ini menstimulasi TSH sehingga terjadi hiperplasia kelenjar sebagai mekanisme kompensasi membentuk lebih banyak hormon tiroid agar kadar T4 dan T3 serum dapat kembali normal. ${ }^{8,11,23}$

Berdasarkan tempat tinggal, kasus kelainan tiroid paling banyak terjadi di daerah pegunungan yaitu sebanyak $66,7 \%$, sedangkan di daerah pesisir pantai yaitu sebanyak 33,3\%. Di Kota Manado, sebagian besar wilayahnya terdiri dari daerah pegunungan, dimana kurang lebih 100 meter dari pantai sudah memasuki wilayah pegunungan. Kelainan tiroid terutama struma tiroid paling sering dialami oleh orang yang tinggal di daerah pegunungan. Hal ini berhubungan dengan faktor geologik dan pola konsumsi dari orang yang tinggal di daerah pegunungan. ${ }^{3}$ Tanah di daerah pegunungan yang jauh dari laut memiliki kandungan yodium yang sedikit. Hal ini dipengaruhi oleh kemiringan tanah yang memudahkan pengikisan lapisan tanah yang mengandung yodium dan curah hujan yang tinggi juga dapat menyebabkan hal tersebut. Faktor lain yang dapat menyebabkan erosi lapisan tanah yang mengandung yodium yaitu penggundulan hutan dan terkikisnya tanah di daerah aliran sungai. ${ }^{8,21,24}$ Selain itu, pola konsumsi masyarakat juga berhubungan dengan banyaknya kejadian tiroid di daerah pegunungan. Bahan pokok pembuat hormon tiroid ialah yodium yang terdapat di alam, terutama dari bahan makanan yang dari laut seperti rumput laut, ganggang laut, ikan laut dan sebagainya. Masyarakat yang tinggal di dearah pegunungan biasanya kurang mengonsumsi makanan yang tinggi yodium. ${ }^{24}$ Banyaknya konsumsi makanan yang goitrogenik seperti ubi kayu, jagung, rebung, ubi jalar dan buncis juga dapat berperan dalam hal ini. ${ }^{24,25}$ Selain itu, pada 
data tersebut terdapat 16 kasus yang data alamat pasien tidak dicantumkan. Hal ini disebabkan karena adanya pengisian status dan surat rujukan pemeriksaan yang tidak mencantumkan tempat tinggal penderita.

Berdasarkan jenis histopatologik, penderita dengan kelainan tiroid jinak terbanyak ialah struma koloides yaitu sebanyak 71,9\%, diikuti adenoma folikular $17,8 \%$, penyakit Grave disease $5,9 \%$, adenoma papilar $3,2 \%$, dan troiditis Hashimoto $1,1 \%$. Hal ini sesuai dengan kepustakaan yang mengatakan bahwa struma tiroid merupakan penyakit tiroid yang paling sering ditemukan. ${ }^{8}$ Gangguan autoimun tiroid pada penelitian ini ditemukan lebih sedikit dari kelainan lainnya dan hal ini sesuai dengan penelitian Swain et al. ${ }^{10}$ yang menyatakan gangguan autoimun tiroid mengenai sekitar 5\% populasi umum, dan $2-4 \%$ populasi perempuan. Pada adenoma tiroid, paling banyak ditemukan adenoma folikular dibandingkan adenoma papilar. Tumor tiroid papiler paling sering ditemukan bersifat ganas, sehingga ketika didiagnosis adenoma tiroid lebih sedikit ditemukan. Namun hal ini masih diperdebatkan karena ada yang berpendapat bahwa tumor papiler harus dianggap karsinoma, sedangkan yang lainnya menyatakan tumor papiler ialah adenoma jinak. $^{26}$

Penderita dengan kelainan tiroid ganas terbanyak ialah karsinoma tiroid papilar yaitu sebanyak 62,7\%, diikuti oleh karsinoma folikular 22\%, karsinoma anaplastik $11,9 \%$, karsinoma papilar varian folikular $1,7 \%$, dan karsinoma medular $1,7 \%$. Hal ini sesuai dengan kepustakaan yang mengatakan bahwa jenis karsinoma tiroid yang paling sering ditemukan ialah karsinoma papilar, dan karsinoma folikuler pada urutan kedua, serta yang paling jarang terjadi karsinoma meduler dan anaplastik. ${ }^{8,21}$ Hal ini juga sejalan dengan penelitian yang dilakukan Sashi dan Sharma $^{27}$ tahun 2015 di Himachal Pradesh India yang menyatakan karsinoma tiroid yang paling banyak ialah karsinoma papilar dengan proporsi $51,2 \%$, dan disusul oleh karsinoma folikular dengan proporsi
26,7\%. Selain itu sebagian besar kepustakaan menyatakan bahwa angka kejadian karsinoma papilar sebesar $80 \%$ $85 \%$, sedangkan pada penelitian ini hanya ditemukan 62,7\%. Di Amerika, peningkatan kejadian karsinoma papilar terjadi seiring dengan peningkatan asupan yodium. Insiden yang lebih tinggi dari kanker tiroid terjadi pada daerah yang telah melakukan profilaksis yodium terhadap gondok. Dominasi kanker papilar lebih tinggi dari karsinoma tiroid folikular di daerah kelebihan yodium, dan di sisi lain defisiensi yodium biasanya dikaitkan dengan karsinoma folikular. Hal ini dapat menjelaskan angka kejadian karsinoma papilar pada penelitian ini ditemukan sebanyak $62,7 \%$ dan karsinoma folikular $22 \%$. Pengetahuan masyarakat tentang konsumsi yodium dapat berpengaruh dalam hal ini, dimana masyarakat di kota Manado kurang memperhatikan asupan yodium yang dimakan berbeda dengan masyarakat di Amerika, sehingga kebutuhan yodium yang diperlukan tidak terpenuhi. Hal ini dapat berhubungan dengan peningkatan kejadian karsinoma folikuler pada penelitian ini. ${ }^{28}$

\section{SIMPULAN}

Pola kelainan tiroid yang paling banyak di RSUP Prof. Dr. R. D. Kandou Manado ialah struma dengan golongan usia 51-60 tahun dan jenis kelamin perempuan. Kelainan tiroid menurut tempat tinggal paling sering terjadi di daerah pegunungan. Menurut jenis histopatologiknya paling sering terjadi ialah struma koloides pada kelainan tiroid jinak dan karsinoma papilar pada kelainan tiroid ganas.

\section{DAFTAR PUSTAKA}

1. Pusat Data dan Informasi Kementrian Kesehatan RI. Infodatin situasi dan analisis gangguan tiroid. Jakarta: Kementrian Kesehatan RI, 2015; p. 1.

2. Bose A, Sharma N, Hemvani N, Chitnis DS. A hospital based prevalence study on thyroid disorders in Malwa region of Central India. Int J Curr Microbiol App Sci. 2015;4:604-11. 
3. Aryal M, Gyawali P, Rajbhandari N, Aryal P, Pandeya DR. A prevalence of thyroid dysfunction in Kathmandu University Hospital, Nepal. Biomed Res. 2010;21:411-5.

4. Khan A, Khan MMA, Akhtar S. Thyroid disorder, etiology and prevalence. J Med Sci. 2002;2:89-94.

5. Raikhy KSS, Bhargava A. The quest for a miracle cure. Thyroid Disorders Ther. 2015;4:2.

6. James R, Kumar VTV. Study on the prevalence of thyroid disease in Ernakulam city and Cherthala town of Kerala State, India. Int J Sci Res Pub. 2012;2:1-3.

7. Tandra H. Mencegah dan mengatasi penyakit tiroid. Jakarta: Gramedia Pustaka Utama, 2011; p. 1-30.

8. Maitra A, Kumar V. Sistem endokrin. In: Kumar V, Cotran RS, Robbins SL, editors. Patologi Robbins volume 2. (7th ed). Jakarta: EGC, 2012; p. 81824.

9. Lamfom HA. Thyroid disorders in Makkah Saudi Arabia. Ozean J Appl Sci. 2008; $1: 55-8$

10. Swain M, Swain T, Mohanty BK. Autoimmune thyroid disorders. Indian Clin Biochem. 2005;20:9-17.

11. Nagarkar R, Roy S, Akheel M, Palwe V, Kulkarni N, Pandit P. Incidence of thyroid disorder in India. IJDMS. 2015;2:19-23.

12. John M. Burden of thyroid diseases in India, need for aggressive diagnosis. Medicine Update. 2008;18:334-41.

13. Boyle P, Levin P. World Cancer Repport. Lyon: International Agency for Research on Cancer, 2008; p. 456-7.

14. Vecchia CL, Malvezzi M, Bosetti $C$, Garavello W, Bertuccio P, Levi F, dkk. Thyroid Cancer Mortality and Incidence: A global overview. Int J Cancer. 2014;136:2187-95.

15. Mutalazimah, Mulyono B, Murti B, Azwar S. Karakteristik demografi pada wanita usia subur dengan gangguan fungsi tiroid. Jurnal Kesehatan. 2013;6:123-33.

16. Budiman B, Sumarno I. Hubungan antara konsumsi iodium dan gondok pada siswi berusia 15-17 tahun. Universa Medicina. 2007;26:80-9.

17. Oktahermoniza, Harahap WA, Tofrizal,
Rasyid R. Analisis ketahanan hidup lima tahun kanker tiroid yang dikelola di RSUP Dr. M. Djamil Padang. Jurnal Kesehatan Andalas. 2013;2:151-7.

18. Achmad D, Sebastian J, Hernowo BS, Rizki KA. Ekspresi protein B-RAF mutan pada karsinoma tiroid papilifer yang bermetastasis ke kelenjar getah bening regional. MKB. 2013;45:24550.

19. Pasaribu ET. Epidemiologi dan gambaran klinis kanker tiroid. Jurnal Kedokteran Nusantara. 2006;39:2703.

20. Handayani SHS, Purnami SW. Pendekatan metode classification and regression tree untuk diagnosis keganasan kanker pada pasien kanker tiroid. Jurnal Sains dan Seni Pomits. 2014;3:24-29.

21. Murtedjo U, Iyad HA, Manoppo AE, Manuaba TJ. Sistem Endokrin. In: Sjamsuhidajat R, Karnadiharja W, Prasetyono TOH, Rudiman R, editors. Ilmu Bedah (3rd ed). Jakarta: EGC, 2014; p. 806-14.

22. Pusat Data dan Informasi Kementrian Kesehatan RI. Infodatin stop cancer. Jakarta: Kementrian Kesehatan RI, 2015; p. 5.

23. Assagaf SM, Lumintang N, Lampus $\mathbf{H}$. Gambaran eutiroid pada pasien struma multinodusa non-toksik di bagian bedah RSUP Prof. Dr. R. D. Kandou Manado periode Juli 2012 Juli 2014. e-Cl. 2015;3:758-62.

24. Pramono B, Purnomo LB, Sinorita $H$. Gondok Endemik. In: Setia S, Alwi I, Sudoyo AW, Simadibrata KM, Setiyohadi B, Syam AF, editors. Ilmu Penyakit Dalam jilid 2 (6th ed). Jakarta: Interna Publishing, 2014; p. 2464-70.

25. Putri E, Khambri D, Renita RS. Hubungan daerah tempat tinggal dengan gambaran histopatologi karsinoma tiroid pada masyarakat Sumatra Barat. Jurnal Kesehatan Andalas. 2014;3:147-50.

26. Masjhur JS. Nodul Tiroid. In: Setia S, Alwi I, Sudoyo AW, Simadibrata KM, Setiyohadi B, Syam AF, editors. Ilmu Penyakit Dalam jilid 2 (6th ed). Jakarta: Interna Publishing, 2014. p. 
Crosby, Pontoh, Merung: Pola kelainan tiroid...

2455-63.

27. Shasi A, Sharma N. Prevalence and clinical aspects of thyroid disorders in Himachal Pradesh, India. Int J Basic Appl Med Sci. 2015;5:86-94.
28. Wartofsky L. Increasing world incidence of thyroid cancer: Increased detection or higher radiation exposure. Hormones. 2010;9:103-8. 